\title{
Pathophysiological basis of cardiovascular disease and depression: a chicken-and-egg dilemma
}

\section{Bases fisiopatológicas da doença cardiovascular e depressão: um dilema do ovo e da galinha}

\author{
Gilberto Paz-Filho, ${ }^{1}$ Julio Licinio, ${ }^{1}$ Ma-Li Wong ${ }^{1}$ \\ ${ }^{1}$ The John Curtin School of Medical Research, Australian National University, Canberra, Australia
}

\begin{abstract}
Objective: To describe the pathophysiological basis linking cardiovascular disease (CVD) and depression; to discuss the causal relationship between them, and to review the effects of antidepressant treatment on cardiovascular disease. Method: A review of the literature based on the PubMed database. Discussion: Depression and cardiovascular disease are both highly prevalent. Several studies have shown that the two are closely related. They share common pathophysiological etiologies or co-morbidities, such as alterations in the hypothalamic-pituitary axis, cardiac rhythm disturbances, and hemorheologic, inflammatory and serotoninergic changes. Furthermore, antidepressant treatment is associated with worse cardiac outcomes (in case of tricyclics), which are not observed with selective serotonin reuptake inhibitors. Conclusion: Although there is a strong association between depression and cardiovascular disease, it is still unclear whether depression is actually a causal factor for CVD, or is a mere consequence, or whether both conditions share a common pathophysiological etiology. Nevertheless, both conditions must be treated concomitantly. Drugs other than tricyclics must be used, when needed, to treat the underlying depression and not as mere prophylactic of cardiac outcomes.
\end{abstract}

Descriptors: Heart; Depression; Cardiovascular disease; Coronary artery disease; Antidepressive agents/adverse effects

\section{Resumo}

Objetivo: Descrever as bases fisiopatológicas que servem de elo entre doenças cardiovasculares e depressão; discutir as relaçôes de causalidade dentre tais entidades e os efeitos do tratamento com antidepressivos sobre doenças cardiovasculares. Método: Uma revisão da literatura baseada no banco de dados PubMed. Discussão: A depressão e doenças cardiovasculares são duas doenças altamente prevalentes. Vários estudos mostraram que ambas as doenças são intimamente ligadas. Elas apresentam etiologias ou comorbidades em comum, tais como alteraçôes no eixo hipotalamico-pituitário, distúrbios de ritmo cardíaco e alteraçôes hemorreológicas, inflamatórias e serotoninérgicas. Além disso, o tratamento com antidepressivos está associado com pior prognóstico cardíaco (no caso de tricíclicos), o que não é observado com inibidores seletivos da recaptação da serotonina. Conclusão: Apesar de haver uma forte associação entre depressão e doenças cardiovasculares, é ainda incerto se a depressão é na verdade o fator causal para doenças cardiovasculares, uma mera consequência, ou se ambas as condiçôes dividem uma etiologia fisiopatológica em comum. De qualquer maneira, ambas as doenças devem ser tratadas concomitantemente. Para evitar comprometimento cardíaco, drogas não-tricíclicas devem ser usadas, quando necessário, para o tratamento da depressão e não como meros profiláticos de eventos cardíacos.

Descritores: Coração; Depressão; Doenças cardiovasculares; Doença da artéria coronariana; Antidepressivos/efeitos adversos

\section{Introduction}

Major depressive disorder (MDD), described by Hippocrates as melancholia 2,500 years ago, was one of the first medical disorders of unknown etiology to be fully characterized as a clinical entity. It is primarily manifested in a triad of symptoms: sadness and its correlates (feelings of worthlessness, guilt and suicidality); lack of pleasure or interest in activities; and low levels of energy, or fatigability. Currently, in the general population, the point prevalence of $\mathrm{MDD}$ is about $4 \%$ to $7 \%,{ }^{1,2}$ whereas lifetime prevalence estimates range from $15 \%$ to $20 \%{ }^{2,3}$ MDD is more prevalent in women (the female:male ratio is typically $2: 1$, but it can be as high as 5:2) and its median age of onset is 25 years. ${ }^{4}$ Depressed patients have decreased life expectancy, and cardiovascular disease (CVD) may be one possible explanation for the increased risk of premature death in those patients.

Among adults $\geq 20$ years old, the prevalence of coronary heart disease is $8.6 \%$ in men and $6.8 \%$ in women. Among adults at age 60 to 79 , the prevalence is $24.4 \%$ in men and $15.1 \%$ in women. According to data from the National Health and Nutrition Surveys
Submitted: November 9, 2009

Accepted: March 10, 2010

\section{Correspondence}

Ma-Li Wong

Building 131, Garran Road, Acton ACT 0200, Australia

Phone: +61-2-61258557

E-mail: mali.wong@anu.edu.au 
(NHANES), the incidence of myocardial infarction (MI) for white men is about $0.9 \%$ at ages 35 to 44 years, $3.0 \%$ at 45 to 54 years, $6.1 \%$ at 55 to 64 years, and $9.2 \%$ at 65 to 74 years. For women, the estimates are substantially lower: 0.3, 1.0, 2.4, and $5.1 \%$, respectively. The sex ratio for incidence of coronary events narrows progressively with advancing age, but the incidence is still higher for men than for age-matched women. The incidence at ages 65 to 94 compared to ages 35 to 64 more than doubles in men and triples in women. ${ }^{5}$ But compared to men, women's CVD (cardiovascular disease) risk is increased to a greater extent by some traditional risk factors (such as diabetes, hypertension, hypercholesterolemia and obesity), as well as by socioeconomic and psychologicalfactors. ${ }^{6}$

Despite a long anecdotal link between CVD and depression, this relationship has only been investigated in depth over the past 15 years. ${ }^{7}$ The mechanisms linking depression to CVD and cardiac mortality are not yet well established. There are three plausible hypotheses that could account for their co-morbidity, and each of them will be discussed in this article. We will discuss here the pathophysiological basis for the association between depression and CVD and will conclude with a discussion of the impact of pharmacological treatment of depression on CVD.

\section{Method}

We selected the most relevant studies in the literature using the PubMed database, with the keywords "heart disease", "coronary disease", "depression", "cardiovascular disease" and "mood disorder". The manuscripts included in this article were selected based on their methodological aspects and the strength of their findings. We addressed this important topic comprehensively in three major areas: 1) the causal relationship between depression and CVD, 2) the pathophysiological basis for that relationship, and 3) the impact of pharmacological treatment for depression on CVD.

\section{Discussion}

\section{Causal relationship between depression and CVD}

A link between the mind and the heart was proposed by William Harvey in 1628. It was only over 300 years later that the aforementioned link was first demonstrated by Frasure-Smith et al., in a study showing that patients who are depressed at the time of an acute myocardial infarction (MI) have markedly elevated mortality as compared with patients who are not depressed. ${ }^{8}$

Since then, more than 200 studies have demonstrated an association between depression and CVD. ${ }^{9-18}$ However, the causal relationship between the two conditions remains unclear. There are three hypotheses that can explain that relationship: 1) depression causes CVD; 2) depression is a consequence of CVD; and 3) depression and CVD share common underlying processes.

1) Hypothesis 1: Depression as a cause of CVD

There is compelling evidence that depression is an independent risk factor for both the development of CVD and for worsening prognosis once CVD is established. Depression is linked to metabolic syndrome (MetS) and CVD. ${ }^{11,16,19-24}$ as reported by the large INTERHEART multi-centric study. In that study, stress and depression were risk factors for first myocardial infarction (MI) in healthy individuals. ${ }^{25}$ The study compared 12,461 acute MI cases with 14,637 matched controls in 54 countries on eight traditional risk factors for coronary heart disease and a composite index of psychosocial factors. The population-attributable risk of the combined psychosocial factors was 33\%, with $9 \%$ of this attributable to depression. The odds ratio was comparable to those reported for other major risk factors (OR: 1.55; CI 1.42-1.69). After adjustment for geographic and ethnic context, the index remained a strong predictor of MI.

In a prospective cohort study of healthy individuals, current or past (in the previous 12 months) depression increased by 2.7 times the risk of dying from ischemic heart disease. ${ }^{26}$ According to other prospective studies with population samples and to case-control studies, depression in patients without coronary heart disease increases the adjusted relative risk for the subsequent development of coronary artery disease 1.5 -fold to 2.0 -fold. ${ }^{27-34} \mathrm{~A}$ meta-analysis indicated that depression nearly doubles the risk of cardiac events, ${ }^{11}$ comparable to the risk conferred by the traditional risk factors, such as dyslipidemia, diabetes and hypertension. ${ }^{20}$ Another meta-analysis demonstrated that depression is an independent risk factor for coronary artery disease, with an overall risk ratio of $1.64 .{ }^{13}$ Numerous additional meta-analyses examining the role of depression in cardiovascular morbidity and mortality have also demonstrated the correlation between depression and cardiovascular disease. ${ }^{10,16,35-37}$

It is currently evident that depression adversely affects the course of several cardiovascular conditions. Once CVD is established, depression impacts negatively on the prognosis, increasing the risk of both further cardiac events and of mortality. Several randomized studies have shown that depression leads to poorer prognosis in patients with existing CVD. In patients who have had an acute $\mathrm{MI}$, depression is a significant risk factor for recurrent non-fatal MI and cardiac mortality. ${ }^{19,21,35,36,38-45}$ In patients with preexisting CVD, depression increases the risk of death by up to 4 -fold. ${ }^{24}$

Depression may be the underlying cause of CVD by causing alterations in the heart function and rhythm (with and without the use of antidepressants), by increasing coagulability and platelet aggregation, by predisposing individuals to unhealthy lifestyles, by altering the hypothalamic-pituitary-adrenocortical (HPA) axis, by increasing inflammation, by increasing autonomic tone, and by causing endothelial dysfunction, among other less well-known processes. However, it is not possible to determine whether those conditions are caused by depression or whether they are part of the underlying co-morbidities. The mechanisms linking depression and CVD will be discussed in due course.

2) Hypothesis 2: Depression as a consequence of CVD

The prevalence of depression after an acute myocardial infarction (MI) is high. About $20 \%$ of patients post-MI have depression, and up to $40 \%$ of patients have at least one symptom of depression. ${ }^{46}$ Another study showed that depression is three times more common in patients after an MI than in the general population. ${ }^{14}$ Therefore, it is also possible that depression is a consequence, not a cause, of CVD. 
Depression causes a greater increase in the incidence of CVD in women. Conversely, women with CVD seem to experience higher levels of depression when compared to men. ${ }^{6}$ In a compilation of 27 studies that reported rates or risks of depression in coronary disease samples, ${ }^{47}$ it was observed that all of those studies had reported clinically or statistically significant rates or risks of at least one measure of depression. Concomitantly, among depressed patients, the same compilation showed that, among 47 studies evaluating the risk of coronary disease in depressed patients, 20 reported rates or risks of coronary disease events in depressed samples. All but one study reported at least one significantly increased rate or risk of coronary disease in the depressed group compared to the non-depressed group. Several cross-sectional studies have shown that the prevalence of depression (DSM-IV criteria) in coronary artery disease patients ranges from 15 to $20 \%,{ }^{8,48-51}$ which is two to four times higher than the prevalence in the general community.

Patients with CVD may become depressed as a reaction to the burden of a co-morbid condition. ${ }^{12}$ In that case, the alterations that could explain why depression would lead to CVD (changes in heart function and rhythm, hypercoagulability and increased platelet aggregation, lack of adherence to medication and healthy lifestyles, changes in the HPA axis, and increased inflammation) might be just markers of CVD and not its determinants.

However, studies that used risk adjustment for cardiac and non-cardiac disease burden in their analyses showed that these variables do not appear to eliminate the relationship, supporting the hypothesis that depression is an independent predictor of outcome. ${ }^{52}$ Furthermore, depression precedes cardiovascular disease in multiple studies.

3) Hypothesis 3: Depression and CVD share common underlying processes

Depression and CVD may be the consequences of a disseminated vascular disease, causing lesions to the brain and to the heart, due to vascular and subsequent metabolic changes. In addition, the relationships between plasminogen activator inhibitor-1 (PAI-1), tissue plasminogen activator (tPA) and brain-derived neurotrophic factor (BDNF) could be the underlying processes common to both diseases.

It is statistically impossible to prove the direction of causality between depression and CVD. ${ }^{53}$ Mosovich et al. have proposed a new model, where depression and CVD share a common underlying cause, and both diseases are possible outcomes of prior stress-related insult to the body. ${ }^{53}$ In that model, local and systemic events, mediated by immune intercellular messengers, would lead to neurotoxicity and disrupted production of serotonin, which in turn would cause depression and increase platelet aggregation.

\section{Review of the pathophysiological mechanisms that could link depression and CVD}

While the causal relationship between depression and CVD is not clearly understood, a number of associations have been proposed to demonstrate the plausibility and coherence of such a relationship. These include both direct biological and behavioral mechanisms linking depression and CVD.
1) Changes in cardiac rhythms and cardiac autonomic tone

As a result of decreased parasympathetic control and increased sympathetic stimulation due to overstimulation of the HPA axis in depressed patients, those patients present more frequent episodes of ventricular tachycardia, ${ }^{54}$ decreased heart rate variability, ${ }^{54-56}$ reduced baroreflex sensitivity, ${ }^{57}$ increased QT variability, ${ }^{58}$ and increased QT dispersion. ${ }^{59}$

Tricyclics have been shown to be associated with increased cardiac risk, ${ }^{60}$ by increasing heart rate, weight and insulin resistance, and by inducing orthostatic hypotension, slow intraventricular cardiac conduction and proarrhythmic cardiac activity. ${ }^{61,62}$ However, depression by itself, without the use of antidepressants, is associated with increased cardiac sympathetic tone / decreased parasympathetic activity ${ }^{63,64}$ and decreased heart rate variability, which have been shown to be associated with increased risk of cardiac mortality. ${ }^{65}$ In a Japanese study involving elderly depressed patients, these changes in sympathetic and parasympathetic tone were most evident in men, which could explain the gender differences in the association of depression with morbidity and mortality. ${ }^{66}$

The direct association between rhythm disturbances and depression is not so clear. Most probably, rhythm disturbances that are observed in depressed patients, in the absence of antidepressant use, may be part of another process, such as hypercortisolism, or of disease of the heart itself. Another possible explanation is that the parasympathetic nervous system is directly linked to the etiology of depression, ${ }^{67}$ as depressed individuals show less context-appropriate vagal withdrawal. ${ }^{64}$

2) Hemorheologic alterations

Depression and stress are related to sympathetically-mediated changes in blood viscosity and hemoconcentration, such as hematocrit and total plasma protein, which are associated with CVD. ${ }^{68-74}$ These alterations, in addition to being mediated by catecholamines (which increase sinus rate, myocardial oxygen consumption and capillary hydrostatic pressure, leading to reduction of plasma volume), ${ }^{75}$ are also linked to increases in blood pressure. ${ }^{76-78}$

In a secondary analysis of a randomized trial, we have found that Mexican-American individuals with mild to moderate depression presented hemorheologic measures of stress-related hemoconcentration, and that those measures decreased significantly after 8 weeks of treatment with either fluoxetine or desipramine. ${ }^{74}$ In that case, hemoconcentration was at least partially explained by sympathetic nervous system activation.

By increasing hemoconcentration, depression may increase blood viscosity, which leads to a decrease in pressure at vulnerable branching sites of coronary arteries and increased exposure time to atherogenic substances. ${ }^{76}$

3) Increased platelet aggregation

Common to depression and to vascular thrombosis, the serotoninergic signaling pathway is important in the etiology and pathogenesis of both disorders. ${ }^{79}$ Brain monoamines play a central role in the genesis of affective disorders, and serotonin potentiates platelet aggregation. More than $99 \%$ of the serotonin in the body is 
found in the dense granules of platelets. ${ }^{80}$ The uptake, storage and metabolism of serotonin are similar in platelets and neurons and the same gene encodes for the serotonin transporter in both cell types. ${ }^{79}$

Patients with depression have platelet abnormalities, due to alterations in the serotonin metabolism. ${ }^{81}$ In these patients, platelets are more likely to degranulate thrombogenic substances, increasing the risk of CVD. High platelet serotonin levels have been associated with thrombosis, whereas lower levels are associated with increased bleeding. ${ }^{82}$ Studies have found contradictory results regarding platelet serotonin levels in depressed patients. Most of the studies showed that platelet serotonin levels are not altered in depressed patients, and few studies observed that only depressed females, not males, have low platelet serotonin levels, ${ }^{83}$ which would predispose to bleeding, not to thrombogenesis. Alterations in the platelet serotonin 5-HT2A (5-hydroxytryptamine 2A) receptors may also contribute to increasing thrombogenesis in depressed patients. However, there are discrepancies in the literature. Some studies show that the number of receptors is increased in those patients, ${ }^{84,85}$ and others suggest that there is no change regarding the density of receptors. ${ }^{86}$ Moreover, the sensitivity of the receptor may be elevated in depressed patients. Some studies showed that depression is associated with a hyperactive 5-HT2A receptor signal transduction system and increased responsiveness of platelets to serotonin. ${ }^{87-89}$ However, those findings have not been replicated by others. ${ }^{90}$

By using $\left[{ }^{3} \mathrm{H}\right]$-imipramine, studies have been suggested that depressed patients have decreased serotonin transporter (SERT) function in their platelets, which would increase serotonin concentration and increase vasoconstriction and thrombosis. ${ }^{91}$ However, studies using $\left[{ }^{3} \mathrm{H}\right]$-paroxetine have not replicated those findings. ${ }^{92,93}$

In addition, increased platelet aggregation may be seen in patients with depression, due to decreased platelet and endothelial nitric oxide synthase (eNOS) activity and plasma levels of NO. ${ }^{94}$ These decreases in NO may be attributed to the downregulation exerted by C-related protein (CRP), which is increased in depressed patients. ${ }^{95}$

Disturbances in blood clotting proteins regulating platelet aggregation may also be responsible for thrombogenesis. The glycoprotein (GP) IIb/IIIa complex is a receptor for fibrinogen, fibronectin, vitronectin, Von Willebrand factor, and thrombospondin. GP Ib/IX receptors lead to a conformational change and activation of GP IIb/IIa receptors, and the expression of both receptors promotes platelet aggregation. Studies have shown that the expression of GP IIb/IIIa, as well as of GP Ib/IX receptors, is increased in depressed patients. ${ }^{96-98}$

Other explanations for increased platelet aggregation in depressed patients could be increased levels of platelet P-selectin and monoamine oxidase activity. ${ }^{83}$ Both substances have been associated with increased platelet aggregation.

In addition to the serotoninergic system, the adrenergic system also regulates platelet function and may be related to increased thrombogenesis in depressed patients. Some studies have shown that these patients have a higher density of platelet alpha-2A receptors, as well as increased sensitivity. ${ }^{99}$ In response to adrenaline, increased platelet aggregation may be observed. ${ }^{100}$

Vascular endothelial dysfunction is also associated with increased platelet aggregation and thrombogenesis. Some studies showed a correlation between depression and endothelial dysfunction, ${ }^{101,102}$ which in turn can lead to CVD. However, it is unclear whether the dysfunction is caused by the depression itself, the antidepressant therapy or a combination of the two.

4) Behavioral factors

Poor compliance with advice to adhere to a healthy lifestyle (e.g. through adequate diet and physical activity), ${ }^{103,104}$ and to take medication that lowers the risk of CVD (such as statins, anti-hypertensive medication and acetylsalicylic acid) ${ }^{105,106}$ may also explain why depressed patients had an increased prevalence of CVD. It is also known that depressed patients are more likely to be smokers, ${ }^{107}$ which undoubtedly increases the risk of CVD. The Heart and Soul Study, which prospectively evaluated 1017 outpatients with stable coronary heart disease, suggested that the association between depressive symptoms and adverse cardiovascular events is largely explained by behavioral factors, particularly physical inactivity. ${ }^{18}$ However, non-compliance and adoption of unhealthy lifestyles may also be mere markers of depression. ${ }^{108}$

5) Alterations in the HPA axis

The association between depression and hypercortisolism has been extensively described. Depression is associated with higher cortisol levels, non-suppression of endogenous cortisol secretion after dexamethasone administration, and alterations in cortisol circadian rhythms. ${ }^{109-111}$ These changes in the HPA axis determine important cardiovascular alterations, which can lead to CVD. ${ }^{112,113}$

Cortisol has hypertensive and atherogenic effects, and adversely affects components of the MetS (metabolic syndrome), such as such as diabetes, truncal obesity, hypercholesterolemia, hypertriglyceridemia, increased blood pressure, and elevated heart rate. ${ }^{114,115}$ Elevated serial morning plasma cortisol has been associated with moderate to severe coronary atherosclerosis and stenosis. ${ }^{116,117}$ In the InChianti Study, a prospective populationbased study of older Italians, depression scores (per SD increase: $\mathrm{OR}=1.20,95 \% \mathrm{CI}=1.02-1.41$ ) and urinary cortisol levels (per $\mathrm{SD}$ increase: $\mathrm{OR}=1.23,95 \% \mathrm{CI}=1.01-1.51$ ) were significantly associated with the presence of metabolic syndrome. The odds of metabolic syndrome in persons with both depressed mood and urinary cortisol excretion in the highest tertile was 1.84 (95\% $\mathrm{CI}=1.02-3.34)$ compared to persons with neither condition. ${ }^{118}$ Although depressed and non-depressed patients had similar urinary cortisol levels, the association between depression and higher urinary cortisol levels increased the likelihood for metabolic syndrome, which is an important risk factor for CVD.

Cortisol also accelerates insult to vascular endothelial cells, and increases sympathoadrenal activity, which results in vasoconstriction, platelet activation, elevated heart rate and 
rhythm disturbances. All those changes are highly deleterious to the cardiovascular system, predisposing to atherosclerosis, thrombogenesis and coronary disease.

6) Inflammation

Increased levels of tumor necrosis factor and other proinflammatory cytokines, such as such as C-reactive protein (CRP), fibrinogen, interleukin (IL)-1 and IL-6, are often observed in depressed patients, ${ }^{119-121}$ as well as in patients with MetS and CVD. Those substances mediate immune cells' chemoattraction, release of growth factors, muscle cell proliferation and atherosclerosis. At a more advanced phase, they mediate the rupture of the atheromatous plaque. Those substances, released in the depressed state, may contribute to the development of CVD. Depressed patients also present shifts in the relative distribution of $\mathrm{T}$ and B lymphocytes, ${ }^{122}$ which can contribute to the alterations in the inflammation biomarkers. In the WISE study, women with depression had a $70 \%$ higher CRP ( $p=0.0008)$ and a $25 \%$ higher IL-6 ( $\mathrm{p}=0.04)$. Depression was a significant predictor of CVD (hazard ratio 2.58, $\mathrm{p}=0.0009$ ). Both depression and inflammatory biomarkers remained independent predictors of CVD. However, inflammation explained only a small portion of the association between depression and CVD. ${ }^{123}$

However, it is also possible that those immune mediators are the common cause of depression and CVD, via systemic effects or via local endothelial damage and ischemia. ${ }^{124} \mathrm{~A}$ recent prospective study has shown that increased inflammation did not appear to be a likely mechanism for explaining the link between depression and incidence of coronary heart disease. ${ }^{125}$

7) Disseminated vascular disease

Another hypothesis is that both depression and CVD may be the consequences of disseminated vascular disease. This disease would affect not only the heart, leading to CVD, but also the brain, causing depression. ${ }^{126,127}$ Depression may be a direct outcome of subcortical brain lesions caused by cerebral atherosclerosis, in patients with underlying disseminated vascular disease. These lesions may disrupt the striatopallido-thalamo-cortical pathways, ${ }^{128,129}$ which are involved in the pathogenesis of depression. ${ }^{129}$ Therefore, depression, as a metabolic encephalopathy (i.e., a disturbance in cellular metabolism in the brain evoked by conditions of hypoxia, hypoglycemia, oxidative stress and/or inflammation), would be a marker of severe and disseminated vascular disease, of which the most serious outcome would be an MI. In addition, depression may be caused also by blood-borne mediators, such as soluble intercellular adhesion molecule 1 (a cell adhesion biomarker for inflammatory processes), released when disseminated vascular disease is present and targeted against brain structures. ${ }^{130}$

8) Fibrinolytic system and the brain

Recently, dysfunction of the tissue plasminogen activator (tPA)plasmin pathway has also been suggested as a link between major depression and CVD. ${ }^{131}$ tPA is a thrombolytic enzyme, with neuroplastic and apoptotic functions in the brain. ${ }^{132}$ Its expression is upregulated in stress, ${ }^{133}$ and low levels of tPA have been found in depressed patients. ${ }^{134}$ The cleavage of proBDNF to BDNF is regulated by tPA, and low levels of tPA would increase proBDNF and decrease BDNF, which in turn would impair the regulation of neuronal plasticity and survival, playing an important role in the pathogenesis of depression.

Plasminogen activator inhibitor-1 (PAI-1) is a regulator of tPA, and is also involved in the pathogenesis of CVD. As tPA, it is also regulated by stress, ${ }^{135}$ and higher levels of PAI- 1 are found in depressed patients. ${ }^{136,137}$ Since tPA is regulated by PAI-1, higher levels of the latter would increase proBDNF and decrease BDNF and, therefore predispose to depression. In that case, alterations in TPA and PAI-1 levels would be a common cause of CVD and depression.

\section{9) Menopause}

Depression is more prevalent in women. After menopause, their risk for coronary disease increases and becomes closer to that of men. It is therefore worth considering the possibility that depression might be an epiphenomenon, essentially a surrogate marker for female sex and postmenopausal age, which could by themselves explain the observed association between depression and increased risk for coronary disease. In this scenario it would not be depression per se, but estrogen-deficiency, the most important risk factor for coronary disease in postmenopausal women. However, this line of reasoning is flawed, as studies have shown that depressed men are also at higher risk for coronary disease than non-depressed men, which favors the hypothesis that depression is important in the pathogenesis of coronary disease in both men $^{32}$ and women.

10) Other explanations

Other explanations for the increased risk of CVD in depressed patients are reduced baroreflex cardiac control; ${ }^{57}$ endothelial dysfunction; ${ }^{102,138,139}$ and a low red blood cell membrane level of long-chain polyunsaturated fatty acids, ${ }^{140,141}$ which is observed in depressed patients ${ }^{142}$ and is associated with an increased risk of atherosclerosis and sudden death. ${ }^{143}$

In addition, risk factor clustering is frequently observed in depressed patients, ${ }^{144}$ as many of them have increased insulin resistance, ${ }^{145}$ hypertension, ${ }^{146,147}$ visceral fat accumulation, ${ }^{148}$ diabetes $^{149}$ and low levels of homocysteine. ${ }^{150}$ Obesity may predispose to depression in women, ${ }^{151,152}$ but not in men. ${ }^{151}$

The short allele of a functional polymorphism in the promoter region of the serotonin transporter gene (5-HTTLPR) has been shown to predict depression. ${ }^{153-155}$ A study has shown that carriers of that allele have an increased prevalence of depression, and have higher levels of 24-hour urinary norepinephrine excretion. ${ }^{156}$ These increased levels of norepinephrine would enhance sympathetic nervous activation, which would then increase cardiac risk.

\section{Impact of pharmacological treatment of depression on CVD}

In a few uncontrolled studies, serotonin reuptake inhibitors (SSRIs) have been shown to have the opposite outcomes of those of tricyclics, by reducing cardiac risk. ${ }^{157,158}$ However, randomized placebo-controlled trials failed to show cardiac benefits in patients 
using antidepressants.

The SADHART (Sertraline Antidepressant Heart Attack Trial) study was the first trial to investigate the safety and efficacy of sertraline treatment of MDD in patients with CVD. Patients with MDD and either acute MI or unstable angina were randomized to receive sertraline 50 to $200 \mathrm{mg}$ or placebo for 24 weeks. Sertraline was safe and effective in treating severe depression, and did not change cardiac function. When evaluated regarding efficacy in preventing post-MI cardiovascular events, the sertraline group was not superior to placebo in preventing cardiovascular outcomes (death, myocardial infarction, congestive heart failure, stroke, and recurrent angina). ${ }^{159}$

In the Myocardial Infarction Depression Intervention Trial (MIND-IT), 91 depressed patients post-MI were randomized to a 24-week, double-blind, placebo-controlled trial with the SSRI mirtazapine. Antidepressant treatment did not alter long-term depression or improve cardiovascular outcomes (cardiac death or hospital admission for documented non-fatal myocardial infarction, myocardial ischemia, coronary revascularization, heart failure or ventricular tachycardia) in depressed post-MI patients in 18 months of follow-up. ${ }^{160}$

The Canadian Cardiac Randomized Evaluation of Antidepressant and Psychotherapy Efficacy (CREATE) trial compared the efficacy of citalopram (an SSRI) with interpersonal therapy in patients with coronary artery disease. Citalopram was superior to placebo regarding efficacy of depression treatment, and interpersonal therapy had no advantage over clinical management (a shorter, 20-minute supportive intervention). ${ }^{161}$ The authors of that study suggested that an SSRI plus clinical management should be considered as a first-step treatment for patients with coronary artery disease and major depression. That study showed no $12-$ week increased risk of cardiovascular events for citalopram, similar to placebo.

The Enhancing Recovery in Coronary Heart Disease (ENRICHD) study ${ }^{162}$ was designed to evaluate the effects of psychosocial intervention in depressed cardiac patients. This type of intervention did not change the incidence of cardiac events, but did improve depression scores. Moreover, patients who did not respond to cognitive behavioral treatment nor had severe depression received sertraline or other antidepressant drug on a non-randomized basis. In an uncontrolled secondary observational analysis, the authors showed that the treated patients had a $42 \%$ lower incidence of death or recurrent MI. ${ }^{158}$

SSRIs seem to have a better profile as regards to adverse effects, and safety, than tricyclics. However, one should be aware of the effects of SSRIs on platelet aggregation. Patients on SSRIs may have increased bleeding due to those effects, ${ }^{163}$ and these drugs should be used with caution, especially when anticoagulants are also being used.

By 2011, the study known as UPBEAT (Understanding Prognostic Benefits of Exercise and Antidepressant Treatment), which is randomizing 200 patients with elevated depressive symptoms to exercise, treatment with sertraline (an SSRI), or placebo for 4 months, will provide further insight on the roles of SSRIs in heart rate variability, vascular function, inflammation and platelet aggregation. Until then, the effect of SSRIs on cardiac outcomes is unknown - probably null, given the published results of large randomized trials. ${ }^{159-161}$

\section{Conclusion}

There is irrefutable evidence that depression and CVD share common pathways. Both of these conditions are stress-reactive disorders of unknown etiology. Interestingly enough, anxiety traits are also associated with CVD. ${ }^{164}$ It is at present statistically impossible to prove which one of these disorders is the cause, and

\section{Depression \& Cardiovascular Disease Interaction Pathways}

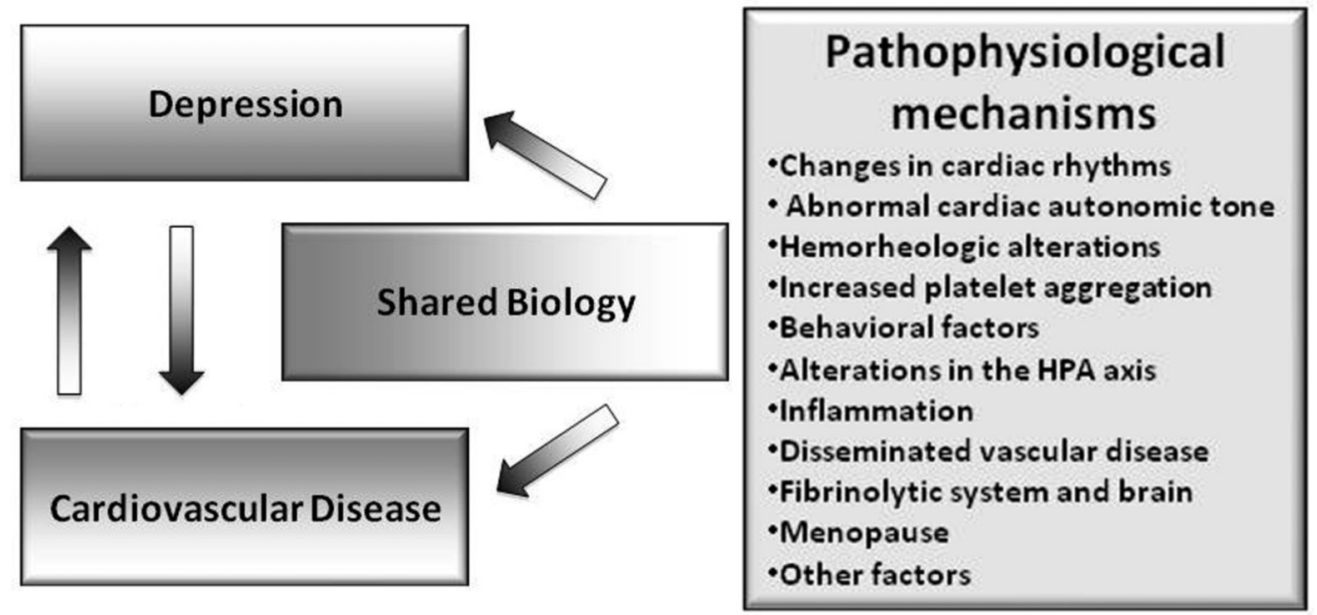

Figure 1 - A proposed conceptual framework for the pathways connecting depression and cardiovascular disease with a summary of the pathophysiological basis for such connections. 
which is the consequence, or whether both share the underlying mechanisms. A better understanding of the heterogeneity of MDD may help clarify its link with CVD. Recently, Kendler et al. have delineated two genetic pathways to depression examining 4,785 twin pairs from the Swedish Twin Registry: 1) a group of high familial loading for MDD, which consists predominantly of patients with early age of onset, and 2) a group of high familial loading for vascular disease, which consists predominantly of patients with late age of onset. ${ }^{165}$ Thus, it would be possible that all three previous hypotheses may not be exclusive. Most likely, the causal relationship varies among patients: in some, depression is the underlying disease, in others, it is the consequence of a heart condition, and in the remainder, both depression and CVD are part of a broader underlying process. Figure 1 summarizes the relationships between depression and CVD, as well as their pathophysiological basis.

In our opinion, this chicken-and-egg dilemma is far from being solved. To minimize morbidity and mortality, it is crucial to understand that MDD and CVD are frequently co-morbid and that both conditions should be treated concomitantly, as the treatment of depression improves the patient's quality of life and their adherence to a regimen of medication for CVD. Although there is preliminary evidence supporting the idea that the treatment of MDD with serotonin reuptake inhibitors (SSRIs) may be useful to reduce the risk of CVD and death, especially in those patients with recurrent and severe depressive symptoms, convincing evidence based on large, randomized control trials is clearly needed. Until such evidence becomes available, is it not justifiable to prescribe SSRIs as a prophylactic for depression in non-depressed patients with CVD.

\section{Acknowledgements}

Our work has been supported by NIH grants GM61394, RR017365, MH062777, RR000865, RR16996, HG002500, and DK063240, and by the Australian National University.

\section{Disclosures}

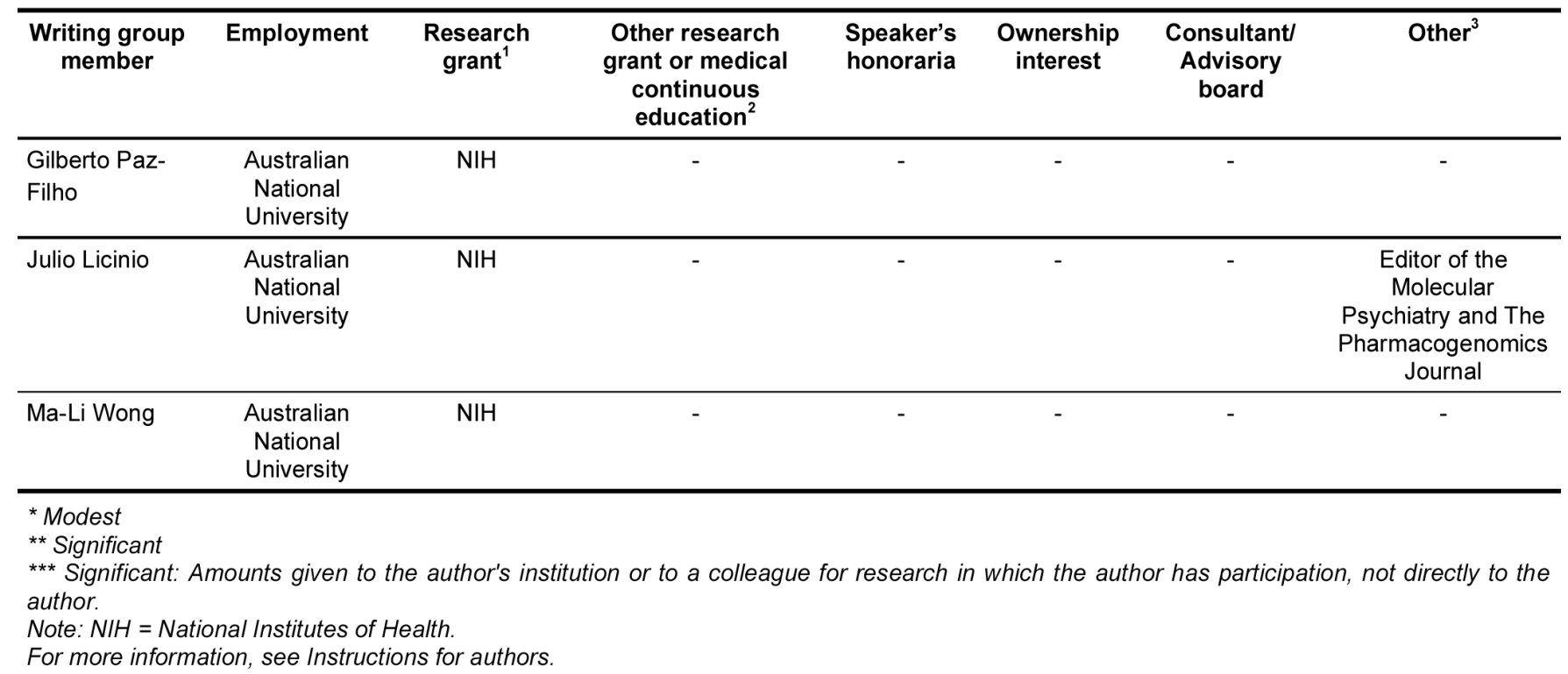

References

1. Regier DA, Narrow WE, Rae DS, Manderscheid RW, Locke BZ, Goodwin FK. The de facto US mental and addictive disorders service system. Epidemiologic catchment area prospective 1-year prevalence rates of disorders and services. Arch Gen Psychiatry. 1993;50(2):85-94.

2. Steffens DC, Skoog I, Norton MC, Hart AD, Tschanz JT, Plassman BL, Wyse BW, Welsh-Bohmer KA, Breitner JC. Prevalence of depression and its treatment in an elderly population: the Cache County study. Arch Gen Psychiatry. 2000;57(6):601-7.

3. Kessler RC, McGonagle KA, Zhao S, Nelson CB, Hughes M, Eshleman S, Wittchen HU, Kendler KS. Lifetime and 12-month prevalence of DSMIII-R psychiatric disorders in the United States. Results from the National Comorbidity Survey. Arch Gen Psychiatry. 1994;51(1):8-19.

4. Burke KC, Burke JD Jr, Regier DA, Rae DS. Age at onset of selected mental disorders in five community populations. Arch Gen Psychiatry. 1990;47(6):511-8.

5. Writing Group M, Lloyd-Jones D, Adams R, Carnethon M, De Simone G, Ferguson TB, Flegal K, Ford E, Furie K, Go A, Greenlund K, Haase N, Hailpern S, Ho M, Howard V, Kissela B, Kittner S, Lackland D,
Lisabeth L, Marelli A, McDermott M, Meigs J, Mozaffarian D, Nichol G, O’Donnell C, Roger V, Rosamond W, Sacco R, Sorlie P, Stafford R, Steinberger J, Thom T, Wasserthiel-Smoller S, Wong N, Wylie-Rosett J, Hong Y, for the American Heart Association Statistics C, Stroke Statistics Subcommittee. Heart Disease and Stroke Statistics-2009 Update: A Report From the American Heart Association Statistics Committee and Stroke Statistics Subcommittee. Circulation. 2009;119(3):e21-181.

6. Moller-Leimkuhler AM. Gender differences in cardiovascular disease and comorbid depression. Dialogues Clin Neurosci. 2007;9(1):71-83.

7. Glassman AH. Depression and cardiovascular comorbidity. Dialogues Clin Neurosci. 2007; 9(1):9-17.

8. Frasure-Smith N, Lesperance F, Talajic M. Depression following myocardial infarction. Impact on 6-month survival. JAMA. 1993;270(15):1819-25.

9. Marano G, Harnic D, Lotrionte M, Biondi-Zoccai G, Abbate A, Romagnoli E, Mazza M. Depression and the cardiovascular system: increasing evidence of a link and therapeutic implications. Expert Rev Cardiovasc Ther. 2009;7(9):1123-47.

10. Nicholson A, Kuper H, Hemingway H. Depression as an aetiologic and prognostic factor in coronary heart disease: a meta-analysis of 6362 events 
among 146538 participants in 54 observational studies. Eur Heart J. 2006;27(23):2763-74.

11. Rugulies R. Depression as a predictor for coronary heart disease. a review and meta-analysis. Am J Prev Med. 2002;23(1):51-61.

12. Rumsfeld JS, Ho PM. Depression and cardiovascular disease: a call for recognition. Circulation. 2005; 111(3):250-3.

13. Wulsin LR, Singal BM. Do depressive symptoms increase the risk for the onset of coronary disease? A systematic quantitative review. Psychosom Med. 2003;65(2):201-10

14. Thombs BD, Bass EB, Ford DE, Stewart KJ, Tsilidis KK, Patel U, Fauerbach JA, Bush DE, Ziegelstein RC. Prevalence of depression in survivors of acute myocardial infarction. J Gen Intern Med. 2006;21(1):30-8.

15. Carney RM, Freedland KE, Steinmeyer B, Blumenthal JA, de Jonge P, Davidson $\mathrm{KW}$, Czajkowski SM, Jaffe AS. History of depression and survival after acute myocardial infarction. Psychosom Med. 2009;71(3):253-9.

16. Goldston K, Baillie AJ. Depression and coronary heart disease: a review of the epidemiological evidence, explanatory mechanisms and management approaches. Clin Psychol Rev. 2008;28(2):288-306.

17. Lett $\mathrm{H}$, Ali S, Whooley M. Depression and cardiac function in patients with stable coronary heart disease: findings from the Heart and Soul Study. Psychosom Med. 2008;70(4):444-9.

18. Whooley MA, de Jonge P, Vittinghoff E, Otte C, Moos R, Carney RM, Ali S, Dowray S, Na B, Feldman MD, Schiller NB, Browner WS. Depressive symptoms, health behaviors, and risk of cardiovascular events in patients with coronary heart disease. JAMA. 2008:300(20):2379-88.

19. Hemingway H, Marmot M. Evidence based cardiology: psychosocial factors in the aetiology and prognosis of coronary heart disease. Systematic review of prospective cohort studies. BMJ. 1999;318(7196):1460-7.

20. Rozanski A, Blumenthal JA, Davidson KW, Saab PG, Kubzansky L. The epidemiology, pathophysiology, and management of psychosocial risk factors in cardiac practice: the emerging field of behavioral cardiology. $J$ Am Coll Cardiol. 2005;45(5):637-51.

21. Rozanski A, Blumenthal JA, Kaplan J. Impact of psychological factors on the pathogenesis of cardiovascular disease and implications for therapy. Circulation. 1999;99(16):2192-217.

22. Thurston RC, Kubzansky LD. Multiple sources of psychosocial disadvantage and risk of coronary heart disease. Psychosom Med. 2007;69(8):748-55.

23. Lett HS, Blumenthal JA, Babyak MA, Sherwood A, Strauman T, Robins C, Newman MF. Depression as a risk factor for coronary artery disease: evidence, mechanisms, and treatment. Psychosom Med. 2004;66(3):305-15.

24. Frasure-Smith N, Lesperance F. Reflections on depression as a cardiac risk factor. Psychosom Med. 2005;67 Suppl 1:S19-25.

25. Yusuf S, Hawken S, Ounpuu S, Dans T, Avezum A, Lanas F, McQueen M, Budaj A, Pais P, Varigos J, Lisheng L. Effect of potentially modifiable risk factors associated with myocardial infarction in 52 countries (the INTERHEART study): case-control study. Lancet. 2004;364(9438):937-52.

26. Surtees PG, Wainwright NW, Luben RN, Wareham NJ, Bingham SA, Khaw KT. Depression and ischemic heart disease mortality: evidence from the EPIC-Norfolk United Kingdom prospective cohort study. Am J Psychiatry. 2008;165(4):515-23.

27. Anda R, Williamson D, Jones D, Macera C, Eaker E, Glassman A, Marks J. Depressed affect, hopelessness, and the risk of ischemic heart disease in a cohort of U.S. adults. Epidemiology. 1993;4(4):285-94.

28. Ariyo AA, Haan M, Tangen CM, Rutledge JC, Cushman M, Dobs A, Furberg CD. Depressive symptoms and risks of coronary heart disease and mortality in elderly Americans. Cardiovascular Health Study Collaborative Research Group. Circulation. 2000;102(15):1773-9.

29. Barefoot JC, Schroll M. Symptoms of depression, acute myocardial infarction, and total mortality in a community sample. Circulation. 1996;93(11):1976-80.

30. Ferketich AK, Schwartzbaum JA, Frid DJ, Moeschberger ML. Depression as an antecedent to heart disease among women and men in the NHANES I study. National Health and Nutrition Examination Survey. Arch Intern Med. 2000;160(9):1261-8.

31. Ford DE, Mead LA, Chang PP, Cooper-Patrick L, Wang NY, Klag MJ. Depression is a risk factor for coronary artery disease in men: the precursors study. Arch Intern Med. 1998;158(13):1422-6.

32. Hippisley-Cox J, Fielding K, Pringle M. Depression as a risk factor for ischaemic heart disease in men: population based case-control study. BMJ. 1998;316(7146):1714-9.

33. Mendes de Leon CF, Krumholz HM, Seeman TS, Vaccarino V, Williams CS, Kasl SV, Berkman LF. Depression and risk of coronary heart disease in elderly men and women: New Haven EPESE, 1982-1991. Established Populations for the Epidemiologic Studies of the Elderly. Arch Intern Med. 1998;158(21):2341-8.

34. Penninx BW, Beekman AT, Honig A, Deeg DJ, Schoevers RA, van Eijk JT, van Tilburg W. Depression and cardiac mortality: results from a community-based longitudinal study. Arch Gen Psychiatry. 2001;58(3):221-7.

35. Barth J, Schumacher M, Herrmann-Lingen C. Depression as a risk factor for mortality in patients with coronary heart disease: a meta-analysis. Psychosom Med. 2004;66(6):802-13.

36. van Melle JP, de Jonge P, Spijkerman TA, Tijssen JG, Ormel J, van Veldhuisen DJ, van den Brink RH, van den Berg MP. Prognostic association of depression following myocardial infarction with mortality and cardiovascular events: a meta-analysis. Psychosom Med. 2004;66(6): 814-22.

37. Van der Kooy K, van Hout H, Marwijk H, Marten H, Stehouwer C, Beekman A. Depression and the risk for cardiovascular diseases: systematic review and meta analysis. Int J Geriatr Psychiatry. 2007;22(7):613-26.

38. Dickens CM, McGowan L, Percival C, Tomenson B, Cotter L, Heagerty A, Creed FH. Contribution of depression and anxiety to impaired healthrelated quality of life following first myocardial infarction. BrJ Psychiatry. 2006; 189:367-72.

39. Jaffe AS, Krumholz HM, Catellier DJ, Freedland KE, Bittner V, Blumenthal JA, Calvin JE, Norman J, Sequeira R, O'Connor C, Rich MW, Sheps D, Wu C. Prediction of medical morbidity and mortality after acute myocardial infarction in patients at increased psychosocial risk in the Enhancing Recovery in Coronary Heart Disease Patients (ENRICHD) study. Am Heart J. 2006;152(1):126-35.

40. Kamphuis MH, Kalmijn S, Tijhuis MA, Geerlings MI, Giampaoli S, Nissinen A, Grobbee DE, Kromhout D. Depressive symptoms as risk factor of cardiovascular mortality in older European men: the Finland, Italy and Netherlands Elderly (FINE) study. Eur I Cardiovasc Prev Rehabil. 2006;13(2):199-206

41. Parashar S, Rumsfeld JS, Spertus JA, Reid KJ, Wenger NK, Krumholz HM, Amin A, Weintraub WS, Lichtman J, Dawood N, Vaccarino V. Time course of depression and outcome of myocardial infarction. Arch Intern Med. 2006;166(18):2035-43.

42. Pedersen SS, Denollet J, Daemen J, van de Sande M, de Jaegere PT, Serruys PW, Erdman RA, van Domburg RT. Fatigue, depressive symptoms, and hopelessness as predictors of adverse clinical events following percutaneous coronary intervention with paclitaxel-eluting stents. $J$ Psychosom Res. 2007;62(4):455-61.

43. Rumsfeld JS, Jones PG, Whooley MA, Sullivan MD, Pitt B, Weintraub WS, Spertus JA. Depression predicts mortality and hospitalization in patients with myocardial infarction complicated by heart failure. Am Heart $J$. 2005;150(5):961-7.

44. Rutledge T, Reis SE, Olson MB, Owens J, Kelsey SF, Pepine CJ, Mankad S, Rogers WJ, Merz CN, Sopko G, Cornell CE, Sharaf B, Matthews KA, Vaccarino V. Depression symptom severity and reported treatment history in the prediction of cardiac risk in women with suspected myocardial ischemia: The NHLBI-sponsored WISE study. Arch Gen Psychiatry. 2006;63(8):874-80.

45. Bunker SJ, Colquhoun DM, Esler MD, Hickie IB, Hunt D, Jelinek VM, Oldenburg BF, Peach HG, Ruth D, Tennant CC, Tonkin AM. "Stress" and coronary heart disease: psychosocial risk factors. Med J Aust. 2003;178(6):272-6.

46. Somberg TC, Arora RR. Depression and heart disease: therapeutic implications. Cardiology. 2008;111(2):75-81.

47. Wulsin LR. Is depression a major risk factor for coronary disease? A systematic review of the epidemiologic evidence. Harv Rev Psychiatry. 2004;12(2):79-93.

48. Carney RM, Rich MW, Freedland KE, Saini J, teVelde A, Simeone C, Clark K. Major depressive disorder predicts cardiac events in patients with coronary artery disease. Psychosom Med. 1988;50(6):627-33.

49. Connerney I, Shapiro PA, McLaughlin JS, Bagiella E, Sloan RP. Relation between depression after coronary artery bypass surgery and 12-month outcome: a prospective study. Lancet. 2001;358(9295):1766-71.

50. Gonzalez MB, Snyderman TB, Colket JT, Arias RM, Jiang JW, O'Connor $\mathrm{CM}$, Krishnan KR. Depression in patients with coronary artery disease. Depression. 1996;4(2):57-62.

51. Jiang W, Alexander J, Christopher E, Kuchibhatla M, Gaulden LH, Cuffe MS, Blazing MA, Davenport C, Califf RM, Krishnan RR, O'Connor $\mathrm{CM}$. Relationship of depression to increased risk of mortality and 
rehospitalization in patients with congestive heart failure. Arch Intern Med. 2001;161(15):1849-56.

52. Mallik S, Krumholz HM, Lin ZQ, Kasl SV, Mattera JA, Roumains SA, Vaccarino V. Patients with depressive symptoms have lower health status benefits after coronary artery bypass surgery. Circulation. 2005;111(3):271-7.

53. Mosovich SA, Boone RT, Reichenberg A, Bansilal S, Shaffer J, Dahlman K, Harvey PD, Farkouh ME. New insights into the link between cardiovascular disease and depression. Int J Clin Pract. 2008;62(3): 423-32.

54. Carney RM, Blumenthal JA, Stein PK, Watkins L, Catellier D, Berkman LF, Czajkowski SM, O'Connor C, Stone PH, Freedland KE. Depression, heart rate variability, and acute myocardial infarction. Circulation. 2001;104(17):2024-8.

55. Carney RM, Freedland KE, Veith RC. Depression, the autonomic nervous system, and coronary heart disease. Psychosom Med. 2005;67 Suppl 1:S29-33.

56. Stein PK, Carney RM, Freedland KE, Skala JA, Jaffe AS, Kleiger RE, Rottman JN. Severe depression is associated with markedly reduced heart rate variability in patients with stable coronary heart disease. $J$ Psychosom Res. 2000;48(4-5):493-500.

57. Watkins LL, Grossman P. Association of depressive symptoms with reduced baroreflex cardiac control in coronary artery disease. Am Heart J. 1999;137(3):453-7.

58. Yeragani VK, Pohl R, Balon R, Jampala VC, Jayaraman A. Twenty-four-hour QT interval variability: increased QT variability during sleep in patients with panic disorder. Neuropsychobiology. 2002;46(1):1-6.

59. Nahshoni E, Aizenberg D, Strasberg B, Dorfman P, Sigler M, Imbar S, Weizman A. QT dispersion in the surface electrocardiogram in elderly patients with major depression. J Affect Disord. 2000;60(3):197-200.

60. Glassman AH, Roose SP, Bigger JT Jr. The safety of tricyclic antidepressants in cardiac patients. Risk-benefit reconsidered. JAMA. 1993;269(20):2673-5.

61. Glassman AH, Roose SP. Risks of antidepressants in the elderly: tricyclic antidepressants and arrhythmia-revising risks. Gerontology. 1994;40 Suppl 1:15-20

62. Ramasubbu R. Insulin resistance: a metabolic link between depressive disorder and atherosclerotic vascular diseases. Med Hypotheses. 2002;59(5):537-51.

63. Udupa K, Sathyaprabha TN, Thirthalli J, Kishore KR, Lavekar GS, Raju TR, Gangadhar BN. Alteration of cardiac autonomic functions in patients with major depression: a study using heart rate variability measures. $J$ Affect Disord. 2007;100(1-3):137-41

64. Rottenberg J. Cardiac vagal control in depression: a critical analysis. Biol Psychol. 2007; 74(2):200-11.

65. Frasure-Smith N, Lesperance F, Talajic M. Depression and 18-month prognosis after myocardial infarction. Circulation. 1995;91(4):999-1005.

66. Chen HC, Yang CC, Kuo TB, Su TP, Chou P. Gender differences in the relationship between depression and cardiac autonomic function among community elderly. Int J Geriatr Psychiatry. 2010:25(3):314-22.

67. Porges SW. The polyvagal theory: phylogenetic substrates of a social nervous system. Int J Psychophysiol. 2001;42(2):123-46.

68. Dintenfass L, Lake B. Blood viscosity factors in evaluation of submaximal work output and cardiac activity in patients with myocardial infarction and angina, and in normals. Bibl Anat. 1977;16 (Pt 2):498-500.

69. Jan KM, Chien S, Bigger JT Jr. Observations on blood viscosity changes after acute myocardial infarction. Circulation. 1975;51(6):1079-84.

70. Lowe GD. Blood rheology in arterial disease. Clin Sci (Lond). 1986;71(2):137-46.

71. Burge PS, Johnson WS, Prankerd TA. Morbidity and mortality in pseudopolycythaemia. Lancet. 1975;1(7919):1266-9.

72. Isbister JP. The contracted plasma volume syndromes (relative polycythaemias) and their haemorheological significance. Baillieres Clin Haematol. 1987;1(3):665-93.

73. Sorlie PD, Garcia-Palmieri MR, Costas R Jr, Havlik RJ. Hematocrit and risk of coronary heart disease: the Puerto Rico Health Program. Am Heart J. 1981;101(4):456-61

74. Wong ML, Dong C, Esposito K, Thakur S, Liu W, Elashoff RM, Licinio J. Elevated stress-hemoconcentration in major depression is normalized by antidepressant treatment: secondary analysis from a randomized, double-blind clinical trial and relevance to cardiovascular disease risk. PLoS ONE. 2008;3(7):e2350.

75. Patterson SM, Matthews KA, Allen MT, Owens JF. Stress-induced hemoconcentration of blood cells and lipids in healthy women during acute psychological stress. Health Psychol. 1995;14(4):319-24.
76. Allen MT, Patterson SM. Hemoconcentration and stress: a review of physiological mechanisms and relevance for cardiovascular disease risk. Biol Psychol. 1995;41(1):1-27.

77. Simonsick EM, Wallace RB, Blazer DG, Berkman LF. Depressive symptomatology and hypertension-associated morbidity and mortality in older adults. Psychosom Med. 1995;57(5):427-35.

78. Wassertheil-Smoller S, Shumaker S, Ockene J, Talavera GA, Greenland P, Cochrane B, Robbins J, Aragaki A, Dunbar-Jacob J. Depression and cardiovascular sequelae in postmenopausal women. The Women's Health Initiative (WHI). Arch Intern Med. 2004;164(3):289-98.

79. Ziegelstein RC, Parakh K, Sakhuja A, Bhat U. Platelet function in patients with major depression. Intern Med J. 2009;39(1):38-43.

80. Skop BP, Brown TM. Potential vascular and bleeding complications of treatment with selective serotonin reuptake inhibitors. Psychosomatics. 1996;37(1):12-6

81. Nemeroff CB, Musselman DL. Are platelets the link between depression and ischemic heart disease? Am Heart J. 2000;140(4 Suppl):57-62.

82. Lechin F, van der Dijs B, Orozco B, Rodriguez S, Baez S. Elective stenting, platelet serotonin and thrombotic events. Platelets. 2004;15(7):462.

83. Parakh K, Sakhuja A, Bhat U, Ziegelstein RC. Platelet function in patients with depression. South Med J. 2008;101(6):612-7.

84. Hrdina PD, Bakish D, Chudzik J, Ravindran A, Lapierre YD. Serotonergic markers in platelets of patients with major depression: upregulation of 5-HT2 receptors. J Psychiatry Neurosci. 1995;20(1):11-9.

85. Hrdina PD, Bakish D, Ravindran A, Chudzik J, Cavazzoni P, Lapierre YD. Platelet serotonergic indices in major depression: up-regulation of 5-HT2A receptors unchanged by antidepressant treatment. Psychiatry Res. 1997;66(2-3):73-85.

86. McBride PA, Brown RP, DeMeo M, Keilp J, Mieczkowski T, Mann JJ. The relationship of platelet 5-HT2 receptor indices to major depressive disorder, personality traits, and suicidal behavior. Biol Psychiatry. 1994;35(5):295-308

87. Shimbo D, Child J, Davidson K, Geer E, Osende JI, Reddy S, Dronge A Fuster V, Badimon JJ. Exaggerated serotonin-mediated platelet reactivity as a possible link in depression and acute coronary syndromes. Am J Cardiol. 2002;89(3):331-3.

88. Eckert A, Gann H, Riemann D, Aldenhoff J, Muller WE. Elevated intracellular calcium levels after 5-HT2 receptor stimulation in platelets of depressed patients. Biol Psychiatry. 1993;34(8):565-8.

89. Kusumi I, Koyama T, Yamashita I. Serotonin-induced platelet intracellular calcium mobilization in depressed patients. Psychopharmacology (Berl) 1994;113(3-4):322-7.

90. McAdams C, Leonard BE. Changes in platelet aggregatory responses to collagen and 5-hydroxytryptamine in depressed, schizophrenic and manic patients. Int Clin Psychopharmacol. 1992;7(2):81-5.

91. Ellis PM, Salmond C. Is platelet imipramine binding reduced in depression? A meta-analysis. Biol Psychiatry. 1994;36(5):292-9.

92. D'Haenen H, De Waele M, Leysen JE. Platelet $3 \mathrm{H}$-paroxetine binding in depressed patients. Psychiatry Res. 1988;26(1):11-7.

93. Lawrence KM, Falkowski J, Jacobson RR, Horton RW. Platelet 5-HT uptake sites in depression: three concurrent measures using $[3 \mathrm{H}]$ imipramine and [3H] paroxetine. Psychopharmacology (Berl). 1993;110(1-2):235-9.

94. Chrapko WE, Jurasz P, Radomski MW, Lara N, Archer SL, Le Melledo JM. Decreased platelet nitric oxide synthase activity and plasma nitric oxide metabolites in major depressive disorder. Biol Psychiatry. 2004;56(2): 129-34.

95. Jarvisalo MJ, Harmoinen A, Hakanen M, Paakkunainen U, Viikari J, Hartiala J, Lehtimaki T, Simell O, Raitakari OT. Elevated serum C-reactive protein levels and early arterial changes in healthy children. Arterioscler Thromb Vasc Biol. 2002;22(8):1323-8.

96. Musselman DL, Marzec UM, Manatunga A, Penna S, Reemsnyder A Knight BT, Baron A, Hanson SR, Nemeroff CB. Platelet reactivity in depressed patients treated with paroxetine: preliminary findings. Arch Gen Psychiatry. 2000;57(9):875-82.

97. Musselman DL, Tomer A, Manatunga AK, Knight BT, Porter MR, Kasey S, Marzec U, Harker LA, Nemeroff CB. Exaggerated platelet reactivity in major depression. Am J Psychiatry. 1996;153(10):1313-7.

98. Walsh MT, Dinan TG, Condren RM, Ryan M, Kenny D. Depression is associated with an increase in the expression of the platelet adhesion receptor glycoprotein Ib. Life Sci. 2002;70(26):3155-65. 
99. Gurguis GN, Vo SP, Griffith JM, Rush AJ. Platelet alpha2A-adrenoceptor function in major depression: Gi coupling, effects of imipramine and relationship to treatment outcome. Psychiatry Res. 1999;89(2):73-95.

100. Garcia-Sevilla JA, Padro D, Giralt MT, Guimon J, Areso P. Alpha 2-adrenoceptor-mediated inhibition of platelet adenylate cyclase and induction of aggregation in major depression. Effect of long-term cyclic antidepressant drug treatment. Arch Gen Psychiatry. 1990;47(2): 125-32.

101.Broadley AJ, Korszun A, Jones CJ, Frenneaux MP. Arterial endothelial function is impaired in treated depression. Heart. 2002; 88(5):521-3.

102. Rajagopalan S, Brook R, Rubenfire M, Pitt E, Young E, Pitt B. Abnormal brachial artery flow-mediated vasodilation in young adults with major depression. Am J Cardiol. 2001;88(2):196-8, A7.

103. Vitaliano PP, Scanlan JM, Zhang J, Savage MV, Hirsch IB, Siegler IC. A path model of chronic stress, the metabolic syndrome, and coronary heart disease. Psychosom Med. 2002;64(3):418-35.

104. van Gool CH, Kempen GI, Penninx BW, Deeg DJ, Beekman AT, van Eijk JT. Relationship between changes in depressive symptoms and unhealthy lifestyles in late middle aged and older persons: results from the Longitudinal Aging Study Amsterdam. Age Ageing. 2003;32(1):81-7.

105. Carney RM, Freedland KE, Eisen SA, Rich MW, Jaffe AS. Major depression and medication adherence in elderly patients with coronary artery disease. Health Psychol. 1995;14(1):88-90.

106. Gehi A, Haas D, Pipkin S, Whooley MA. Depression and medication adherence in outpatients with coronary heart disease: findings from the Heart and Soul Study. Arch Intern Med. 2005;165(21):2508-13.

107. Lehto S, Koukkunen H, Hintikka J, Viinamaki H, Laakso M, Pyorala K. Depression after coronary heart disease events. Scand Cardiovasc J. 2000;34(6):580-3.

108. Ziegelstein RC, Bush DE, Fauerbach JA. Depression, adherence behavior, and coronary disease outcomes. Arch Intern Med. 1998;158(7):808-9.

109. Deuschle M, Weber B, Colla M, Depner M, Heuser I. Effects of major depression, aging and gender upon calculated diurnal free plasma cortisol concentrations: a re-evaluation study. Stress. 1998;2(4):281-7.

110. Holsboer F, von Bardeleben U, Wiedemann K, Muller OA, Stalla GK. Serial assessment of corticotropin-releasing hormone response after dexamethasone in depression. Implications for pathophysiology of DST nonsuppression. Biol Psychiatry. 1987;22(2):228-34.

111. Musselman DL, Nemeroff CB. Depression and endocrine disorders: focus on the thyroid and adrenal system. BrJ Psychiatry Suppl. 1996;30:123-8.

112. Etxabe J, Vazquez JA. Morbidity and mortality in Cushing's disease: an epidemiological approach. Clin Endocrinol (Oxf). 1994;40(4):479-84.

113. van Zaane B, Reuwer AQ, Buller HR, Kastelein JJ, Gerdes VE, Twickler MT. Hormones and cardiovascular disease: a shift in paradigm with clinical consequences? Semin Thromb Hemost. 2009;35(5):478-87.

114. Holsboer F. Stress, hypercortisolism and corticosteroid receptors in depression: implications for therapy. J Affect Disord. 2001;62(1-2):77-91.

115. Rosmond R. Role of stress in the pathogenesis of the metabolic syndrome. Psychoneuroendocrinology. 2005;30(1):1-10.

116. Troxler RG, Sprague EA, Albanese RA, Fuchs R, Thompson AJ. The association of elevated plasma cortisol and early atherosclerosis as demonstrated by coronary angiography. Atherosclerosis. 1977;26(2):151-62.

117. Koertge J, Al-Khalili F, Ahnve S, Janszky I, Svane B, Schenck-Gustafsson $\mathrm{K}$. Cortisol and vital exhaustion in relation to significant coronary artery stenosis in middle-aged women with acute coronary syndrome. Psychoneuroendocrinology. 2002;27(8):893-906.

118. Vogelzangs N, Suthers K, Ferrucci L, Simonsick EM, Ble A, Schrager M, Bandinelli S, Lauretani F, Giannelli SV, Penninx BW. Hypercortisolemic depression is associated with the metabolic syndrome in late-life. Psychoneuroendocrinology. 2007;32(2):151-9.

119. Anisman H, Merali Z. Cytokines, stress, and depressive illness. Brain Behav Immun. 2002;16(5):513-24.

120. Miller GE, Stetler CA, Carney RM, Freedland KE, Banks WA. Clinical depression and inflammatory risk markers for coronary heart disease. Am J Cardiol. 2002;90(12):1279-83.

121. Kop WJ, Gottdiener JS, Tangen CM, Fried LP, McBurnie MA, Walston J, Newman A, Hirsch C, Tracy RP. Inflammation and coagulation factors in persons $>65$ years of age with symptoms of depression but without evidence of myocardial ischemia. Am J Cardiol. 2002;89(4):419-24.

122. Suarez EC, Krishnan RR, Lewis JG. The relation of severity of depressive symptoms to monocyte-associated proinflammatory cytokines and chemokines in apparently healthy men. Psychosom Med. 2003;65(3):362-8.
123. Vaccarino V, Johnson BD, Sheps DS, Reis SE, Kelsey SF, Bittner V, Rutledge T, Shaw LJ, Sopko G, Bairey Merz CN. Depression, inflammation, and incident cardiovascular disease in women with suspected coronary ischemia: the National Heart, Lung, and Blood Institute-sponsored WISE study. J Am Coll Cardiol. 2007;50(21):2044-50.

124. Joynt KE, Whellan DJ, O'Connor CM. Depression and cardiovascular disease: mechanisms of interaction. Biol Psychiatry. 2003;54(3):248-61.

125. Davidson KW, Schwartz JE, Kirkland SA, Mostofsky E, Fink D, Guernsey D, Shimbo D. Relation of inflammation to depression and incident coronary heart disease (from the Canadian Nova Scotia Health Survey [NSHS95] Prospective Population Study). Am J Cardiol. 2009;103(6):755-61.

126. Iosifescu DV, Clementi-Craven N, Fraguas R, Papakostas GI, Petersen T, Alpert JE, Nierenberg AA, Fava M. Cardiovascular risk factors may moderate pharmacological treatment effects in major depressive disorder. Psychosom Med. 2005;67(5):703-6.

127. Krishnan KR, Hays JC, Blazer DG. MRI-defined vascular depression. Am J Psychiatry. 1997;154(4):497-501.

128. Alexopoulos GS. New concepts for prevention and treatment of late-life depression. Am J Psychiatry. 2001;158(6):835-8.

129. Krishnan KR. Neuroanatomic substrates of depression in the elderly.J Geriatr Psychiatry Neurol. 1993;6(1):39-58.

130. Lesperance F, Frasure-Smith N, Theroux P, Irwin M. The association between major depression and levels of soluble intercellular adhesion molecule 1 , interleukin-6, and C-reactive protein in patients with recent acute coronary syndromes. Am J Psychiatry. 2004;161(2):271-7.

131. Hou SJ, Yen FC, Tsai SJ. Is dysfunction of the tissue plasminogen activator (tPA)-plasmin pathway a link between major depression and cardiovascular disease? Med Hypotheses. 2009;72(2):166-8.

132. Yepes M, Lawrence DA. Tissue-type plasminogen activator and neuroserpin a well-balanced act in the nervous system? Trends Cardiovasc Med. 2004;14(5):173-80.

133. Pawlak R, Magarinos AM, Melchor J, McEwen B, Strickland S. Tissue plasminogen activator in the amygdala is critical for stress-induced anxiety-like behavior. Nat Neurosci. 2003;6(2):168-74.

134. Pietraszek MH, Takada Y, Nishimoto M, Ohara K, Takada A. Fibrinolytic activity in depression and neurosis. Thromb Res. 1991;63(6):661-6.

135. Yamamoto K, Takeshita K, Shimokawa T, Yi H, Isobe K, Loskutoff DJ, Saito H. Plasminogen activator inhibitor-1 is a major stress-regulated gene: implications for stress-induced thrombosis in aged individuals. Proc Natl Acad Sci U S A. 2002;99(2):890-5.

136. Eskandari F, Mistry S, Martinez PE, Torvik S, Kotila C, Sebring N, Drinkard BE, Levy C, Reynolds JC, Csako G, Gold PW, Horne M, Cizza G. Younger, premenopausal women with major depressive disorder have more abdominal fat and increased serum levels of prothrombotic factors: implications for greater cardiovascular risk. Metabolism. 2005;54(7):91824.

137. Lahlou-Laforet K, Alhenc-Gelas M, Pornin M, Bydlowski S, Seigneur E, Benetos A, Kierzin JM, Scarabin PY, Ducimetiere P, Aiach M, Guize L, Consoli SM. Relation of depressive mood to plasminogen activator inhibitor, tissue plasminogen activator, and fibrinogen levels in patients with versus without coronary heart disease. Am J Cardiol. 2006;97(9):1287-91

138. Sherwood A, Hinderliter AL, Watkins LL, Waugh RA, Blumenthal JA. Impaired endothelial function in coronary heart disease patients with depressive symptomatology. J Am Coll Cardiol. 2005;46(4):656-9.

139. Kim JH, Kim JW, Ko YH, Choi CU, Na JO, Kim EJ, Rha SW, Park CG, Seo HS, Oh DJ. Coronary endothelial dysfunction associated with a depressive mood in patients with atypical angina but angiographically normal coronary artery. Int J Cardiol. In press 2009.

140. Tiemeier H, van Tuijl HR, Hofman A, Kiliaan AJ, Breteler MM. Plasma fatty acid composition and depression are associated in the elderly: the Rotterdam Study. Am J Clin Nutr. 2003;78(1):40-6.

141. Puri BK. Cardiovascular disease and depression: the PUFA connection. Int J Clin Pract. 2008;62(3):355-7.

142. Edwards R, Peet M, Shay J, Horrobin D. Omega-3 polyunsaturated fatty acid levels in the diet and in red blood cell membranes of depressed patients. J Affect Disord. 1998;48(2-3):149-55.

143. Siscovick DS, Raghunathan TE, King I, Weinmann S, Wicklund KG, Albright J, Bovbjerg V, Arbogast P, Smith H, Kushi LH, et al. Dietary intake and cell membrane levels of long-chain n-3 polyunsaturated fatty acids and the risk of primary cardiac arrest. JAMA. 1995;274(17):1363-7. 
144. Dunbar JA, Reddy P, Davis-Lameloise N, Philpot B, Laatikainen T, Kilkkinen A, Bunker SJ, Best JD, Vartiainen E, Kai Lo S, Janus ED. Depression: an important comorbidity with metabolic syndrome in a general population. Diabetes Care. 2008;31(12):2368-73.

145. Okamura F, Tashiro A, Utumi A, Imai T, Suchi T, Tamura D, Sato Y, Suzuki $S$, Hongo $M$. Insulin resistance in patients with depression and its changes during the clinical course of depression: minimal model analysis. Metabolism. 2000;49(10):1255-60.

146. Davidson K, Jonas BS, Dixon KE, Markovitz JH. Do depression symptoms predict early hypertension incidence in young adults in the CARDIA study? Coronary Artery Risk Development in Young Adults. Arch Intern Med. 2000;160(10):1495-500.

147. Jonas BS, Lando JF. Negative affect as a prospective risk factor for hypertension. Psychosom Med. 2000;62(2):188-96.

148. Vogelzangs N, Kritchevsky SB, Beekman AT, Newman AB, Satterfield S, Simonsick EM, Yaffe K, Harris TB, Penninx BW. Depressive symptoms and change in abdominal obesity in older persons. Arch Gen Psychiatry. 2008;65(12):1386-93.

149. Anderson RJ, Freedland KE, Clouse RE, Lustman PJ. The prevalence of comorbid depression in adults with diabetes: a meta-analysis. Diabetes Care. 2001;24(6):1069-78.

150. Severus WE, Littman AB, Stoll AL. Omega-3 fatty acids, homocysteine, and the increased risk of cardiovascular mortality in major depressive disorder. Harv Rev Psychiatry. 2001;9(6):280-93.

151. Carpenter KM, Hasin DS, Allison DB, Faith MS. Relationships between obesity and DSM-IV major depressive disorder, suicide ideation, and suicide attempts: results from a general population study. Am J Public Health. 2000;90(2):251-7.

152. Istvan J, Zavela K, Weidner G. Body weight and psychological distress in NHANES I. Int J Obes Relat Metab Disord. 1992;16(12):999-1003.

153. McCaffery JM, Frasure-Smith N, Dube MP, Theroux P, Rouleau GA, Duan Q, Lesperance F. Common genetic vulnerability to depressive symptoms and coronary artery disease: a review and development of candidate genes related to inflammation and serotonin. Psychosom Med. 2006;68(2):187-200.

154. Menza MA, Palermo B, DiPaola R, Sage JI, Ricketts MH. Depression and anxiety in Parkinson's disease: possible effect of genetic variation in the serotonin transporter. J Geriatr Psychiatry Neurol. 1999;12(2):49-52.

155. Ramasubbu R, Tobias R, Buchan AM, Bech-Hansen NT. Serotonin transporter gene promoter region polymorphism associated with poststroke major depression. J Neuropsychiatry Clin Neurosci. 2006;18(1):96-9.

156. Otte C, McCaffery J, Ali S, Whooley MA. Association of a serotonin transporter polymorphism (5-HTTLPR) with depression, perceived stress, and norepinephrine in patients with coronary disease: the Heart and Soul Study. Am J Psychiatry. 2007;164(9):1379-84.

157. Sauer WH, Berlin JA, Kimmel SE. Selective serotonin reuptake inhibitors and myocardial infarction. Circulation. 2001;104(16):1894-8.

158. Taylor CB, Youngblood ME, Catellier D, Veith RC, Carney RM, Burg MM, Kaufmann PG, Shuster J, Mellman T, Blumenthal JA, Krishnan R, Jaffe AS. Effects of antidepressant medication on morbidity and mortality in depressed patients after myocardial infarction. Arch Gen Psychiatry. 2005;62(7):792-8.

159. Glassman AH, O'Connor CM, Califf RM, Swedberg K, Schwartz P, Bigger JT Jr, Krishnan KR, van Zyl LT, Swenson JR, Finkel MS, Landau C, Shapiro PA, Pepine CJ, Mardekian J, Harrison WM, Barton D, McLvor M. Sertraline treatment of major depression in patients with acute MI or unstable angina. JAMA. 2002;288(6):701-9.

160. van Melle JP, de Jonge P, Honig A, Schene AH, Kuyper AM, Crijns HJ, Schins A, Tulner D, van den Berg MP, Ormel J. Effects of antidepressant treatment following myocardial infarction. Br J Psychiatry. 2007;190:460-6.

161. Lesperance F, Frasure-Smith N, Koszycki D, Laliberte MA, van Zyl LT, Baker B, Swenson JR, Ghatavi K, Abramson BL, Dorian P, Guertin MC. Effects of citalopram and interpersonal psychotherapy on depression in patients with coronary artery disease: the Canadian Cardiac Randomized Evaluation of Antidepressant and Psychotherapy Efficacy (CREATE) trial. JAMA. 2007;297(4):367-79.

162. Berkman LF, Blumenthal J, Burg M, Carney RM, Catellier D, Cowan MJ, Czajkowski SM, DeBusk R, Hosking J, Jaffe A, Kaufmann PG, Mitchell P, Norman J, Powell LH, Raczynski JM, Schneiderman N. Effects of treating depression and low perceived social support on clinical events after myocardial infarction: the Enhancing Recovery in
Coronary Heart Disease Patients (ENRICHD) Randomized Trial. JAMA. 2003;289(23):3106-16.

163. Ziegelstein RC, Meuchel J, Kim TJ, Latif M, Alvarez W, Dasgupta N, Thombs BD. Selective serotonin reuptake inhibitor use by patients with acute coronary syndromes. Am J Med. 2007;120(6):525-30.

164. Sardinha A, Nardi AE, Zin WA. Are panic attacks really harmless? The cardiovascular impact of panic disorder. Rev Bras Psiquiatr. 2009;31(1):57-62.

165. Kendler KS, Fiske A, Gardner CO, Gatz M. Delineation of two genetic pathways to major depression. Biol Psychiatry. 2009;65(9):808-11. 